\title{
Haematocrit as diagnostic tool for assessing Primary Postpartum haemorrhage
}

\author{
Sneha $\mathrm{K}^{1, *}$, Girish Babu $\mathbf{M}^{2}$, Manjunath $\mathrm{ML}^{3}$ \\ ${ }^{1}$ Tutor, MD Physiology, ${ }^{2}$ Associate Professor, ${ }^{3}$ Professor and Head, Dept. of Physiology, Shivamogga Institute of Medical \\ Sciences, Shivamogga, Karnataka
}

*Correspondence Author:

Email: snehatwincle@gmail.com

Received: $26^{\text {th }}$ September, 2017

Accepted: $28^{\text {th }}$ December, 2017

\begin{abstract}
Introduction: A woman is most vulnerable at the postpartum period. About 50-70\% of maternal deaths occur in the postpartum period, of which $45 \%$ deaths occur in the first 24 hours after delivery and more than two thirds during the first week. Between $11-17 \%$ maternal deaths occur during child birth itself. There is a direct correlation between haemoglobin, haematocrit and red blood corpuscle values with the amount of blood loss. With increase in blood loss, the incidence of PPH will be more.

Materials and Methods: 500 pregnant women of 18-35 years, undergoing vaginal delivery at Mc Gann teaching district hospital, Shivamogga were evaluated for hematological parameters (Hb, Hct, RBC) during their admission for delivery and on first postpartum day. The American College of Obstetrics and Gynecology defines PPH as a 10\% change in haematocrit value between the labour admission and postpartum period.

Results: There was reduction in the mean values of $\mathrm{Hb}, \mathrm{Hct}, \mathrm{RBC}$ and the results were statistically highly significant ( $<<0.001)$. The incidence of primary PPH was $14.8 \%$ as determined by $10 \%$ decrease in hematocrit level.

Conclusion: Laboratory analysis of haematological parameters, being simple and accurate method, has to be followed, even during postpartum period, to assess, to take necessary measures and to prevent primary $\mathrm{PPH}$ and thereby decreasing the maternal morbidity and mortality.
\end{abstract}

Keywords: Postpartum haemorrhage, Visual estimation, Hematocrit.

\section{Introduction}

The pregnancy in a woman's life is a unique state in terms of desirable physiological changes and the exciting reversal of changes soon after the termination of pregnancy. It is considered essential to guarantee a good feto-maternal outcome, by attaining optimal anthropometric and haematological parameters. ${ }^{1}$ Maternal mortality continues to be of increasing concern worldwide, the most important cause being primary PPH. ${ }^{2}$ Even in developed countries such as the United Kingdom, United States and France, severe PPH remains amongst the first two causes of maternal deaths. Worldwide, PPH accounts for about one-fourth of 500,000 women who die of pregnancy related morbidities. ${ }^{3}$

India has a maternal mortality rate of $178 / 1,00,000$ live births estimated for the year $2012 .{ }^{4}$ Hemorrhage is the single most important cause of maternal deaths worldwide. Twenty-five percent of all maternal deaths are due to hemorrhage; the proportions ranges from $<10 \%$ to nearly $60 \%$ in various countries. ${ }^{5}$ The American College of Obstetrics and Gynecology defines PPH as either a 10\% change in haematocrit value between the labour admission and postpartum period or a need for erythrocyte transfusion. ${ }^{6}$

There is a direct correlation between haemoglobin, haematocrit and red blood corpuscle values with the amount of blood loss. With the increase in blood loss, the incidence of PPH will be more. Visual estimation of blood loss has proven not to be a reliable method leading to a gross underestimation of primary PPH by up to $50 \%$. The present study was undertaken to study the changes in blood parameters before and after normal vaginal delivery, and aid in optimal assessment and early diagnosis of primary postpartum haemorrhage.

\section{Aims and Objectives}

1. To evaluate $\mathrm{RBC}, \mathrm{Hb}$ and $\mathrm{Hct}$ at the time of admission for delivery and on $1^{\text {st }}$ postpartum day (12-24hours of delivery).

2. To compare the values obtained from them.

3. To assess the incidence of primary PPH by analysing the results obtained.

\section{Materials and Methods}

Random sample of 500 pregnant females aged between 18-35 years undergoing vaginal delivery at Mc Gann Teaching District Hospital, Shivamogga were selected. Patient's confidentiality was maintained for all women enrolled in the study. The informed consent was explained to the participants in their vernacular language and their questions were answered. Patients were screened for enrolment in the study using the inclusion and exclusion criteria.

\section{Inclusion criteria:}

1. Women in reproductive age groups of 18 to $35 \mathrm{yrs}$. 
2. Vaginal delivery.

3. Singleton pregnancy.

Exclusion criteria:

1. Elective/emergency caesarean sections.

2. PIH/pre-eclampsia.

3. Instrumental deliveries.

4. Prepartum Haemoglobin $<8 \mathrm{gm} \%$.

5. Placental abnormalities.

Patient particulars, general physical examination including pulse rate, blood pressure, respiratory rate were recorded and systemic examination of cardiovascular, respiratory, alimentary and nervous systems was done. $5 \mathrm{cc}$ of venous blood sample was collected with aseptic precautions. Blood samples were taken during the time of their admission to labour ward (pre-delivery) and within $12-24 \mathrm{hrs}$ of $1^{\text {st }}$ postpartum (post-delivery) day analysed in lab. Haemoglobin, Haematocrit, Red blood cell count were estimated using SYSMEX KX-21 Automated Hematology Analyser (Copyright () 1997-2000 by SYSMEX CORPORATION).

\section{Statistical Analysis}

Analysis of the data has been done by using descriptive statistics such as mean and standard deviation and inferential statistics using the paired ttest. Data entry, analysis and preparation of charts and graphs was carried out using Microsoft Office Excel 2007. All values are presented as Mean \pm Standard Deviation (Mean $\pm \mathrm{SD}$ ). Comparison of mean values of parameters between pre-delivery and on $1^{\text {st }}$ postpartum day was done by paired 't' test.

1. $\mathrm{p}$ Value $>0.05$ is taken as not significant.
2. $\mathrm{p}$ Value $<0.05$ is taken as significant.

3. $\mathrm{p}$ Value $<0.01$ is taken as highly significant.

4. $\mathrm{p}$ Value $<0.001$ is taken as very highly significant.

\section{Results}

Table 1 shows the mean and standard deviation of $\mathrm{Hb}$ during pre-delivery and on $1^{\text {st }}$ postpartum day, and $\mathrm{p}$ value of paired ' $t$ ' test. The mean \pm SD of pre-delivery $\mathrm{Hb}$ was found to be $11.5 \pm 1.4 \mathrm{gm} \%$ and of $1^{\text {st }}$ postpartum day was $10.4 \pm 1.3 \mathrm{gm} \%$. This difference was statistically highly significant. $(\mathrm{p}<0.0001)$

Table 2 shows the mean and standard deviation of Hct during pre-delivery and on $1^{\text {st }}$ postpartum day, and $\mathrm{p}$ value of paired ' $\mathrm{t}$ ' test. The mean $\pm \mathrm{SD}$ of predelivery Hct was found to be $33.6 \pm 3.3 \%$ and of $1^{\text {st }}$ postpartum day was $31.4 \pm 3.3 \%$. This difference was statistically highly significant. $(\mathrm{p}<0.0001)$

Table 3 shows the mean and standard deviation of RBC count during pre-delivery and on $1^{\text {st }}$ postpartum day, and $p$ value of paired ' $t$ ' test. The mean \pm SD of pre-delivery RBC count was found to be $4.4 \pm 0.5$ millions/cumm of blood and of $1^{\text {st }}$ postpartum day was $4 \pm 0.5 \mathrm{millions} / \mathrm{cumm}$ of blood. This difference was statistically highly significant. $(\mathrm{p}<0.0001)$

\section{Incidence of primary PPH}

1. Total number of cases with $>10 \%$ variation in haematocrit values between pre-delivery and $1^{\text {st }}$ postpartum day $=74$.

2. Total number of cases involved in the study $=500$.

3. Incidence of primary $\mathrm{PPH}=(74 / 500) \times 100=14.8 \%$

Table 1: Haemoglobin values during pre-delivery and on $1^{\text {st }}$ post-partum day

\begin{tabular}{|l|c|c|c|c|c|}
\hline \multirow{2}{*}{ Parameters } & \multicolumn{2}{|c|}{ Pre-delivery } & \multicolumn{2}{|c|}{$\begin{array}{c}\text { st post-partum } \\
\text { day }\end{array}$} & \multirow{2}{*}{ p-value } \\
\cline { 2 - 5 } & Mean & $\begin{array}{l}\text { Standard } \\
\text { deviation }\end{array}$ & Mean & $\begin{array}{l}\text { Standard } \\
\text { deviation }\end{array}$ & \\
\hline $\begin{array}{l}\text { Haemoglobin } \\
\text { (gm\%) }\end{array}$ & 11.5 & \pm 1.4 & 10.4 & \pm 1.3 & $<0.0001^{*}$ \\
\hline
\end{tabular}

(* p value $<0.0001$ is highly significant)

Table 2: Hematocrit values during pre-delivery and on $1^{\text {st }}$ post-partum day

\begin{tabular}{|c|l|l|l|l|l|}
\hline \multirow{2}{*}{ Parameters } & \multicolumn{2}{|l|}{ Pre-delivery } & \multicolumn{2}{|c|}{$\mathbf{1}^{\text {st }}$ post-partum day } & \multirow{2}{*}{ p-value } \\
\cline { 2 - 5 } & Mean & $\begin{array}{l}\text { Standard } \\
\text { deviation }\end{array}$ & Mean & $\begin{array}{l}\text { Standard } \\
\text { deviation }\end{array}$ & \\
\hline Hematocrit $(\%)$ & 33.6 & \pm 3.3 & 31.4 & \pm 3.3 & $<0.0001 *$ \\
\hline
\end{tabular}

(* p value $<0.0001$ is highly significant)

Table 3: RBC count during pre-delivery and on $1^{\text {st }}$ post-partum day

\begin{tabular}{|c|c|c|c|c|c|}
\hline \multirow[b]{2}{*}{ Parameters } & \multicolumn{2}{|c|}{ Pre-delivery } & \multicolumn{2}{|c|}{$1^{\text {st }}$ post-partum day } & \multirow[b]{2}{*}{ p-value } \\
\hline & Mean & $\begin{array}{l}\text { Standard } \\
\text { deviation }\end{array}$ & Mean & $\begin{array}{l}\text { Standard } \\
\text { deviation }\end{array}$ & \\
\hline $\begin{array}{l}\text { RBC(milli } \\
\text { of blood) }\end{array}$ & 4.4 & \pm 0.5 & 4 & \pm 0.5 & $<0.00$ \\
\hline
\end{tabular}

(* p value $<0.0001$ is highly significant) 


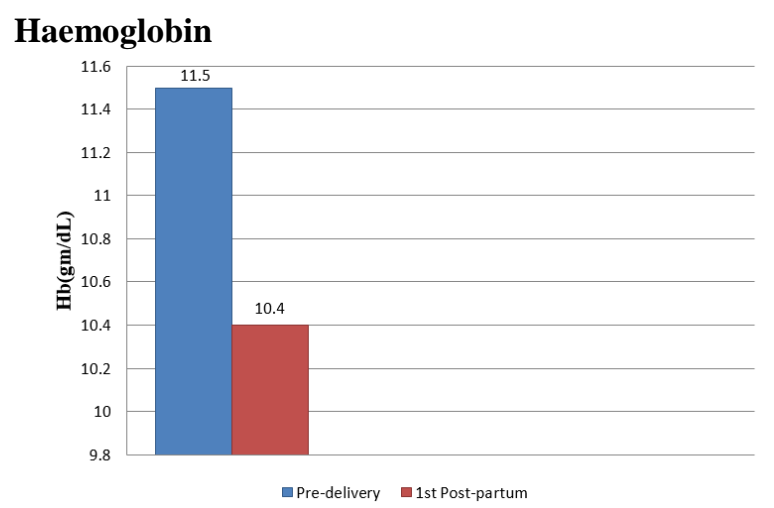

Fig. 1: Mean values of Haemoglobin during predelivery and $1^{\text {st }}$ postpartum day

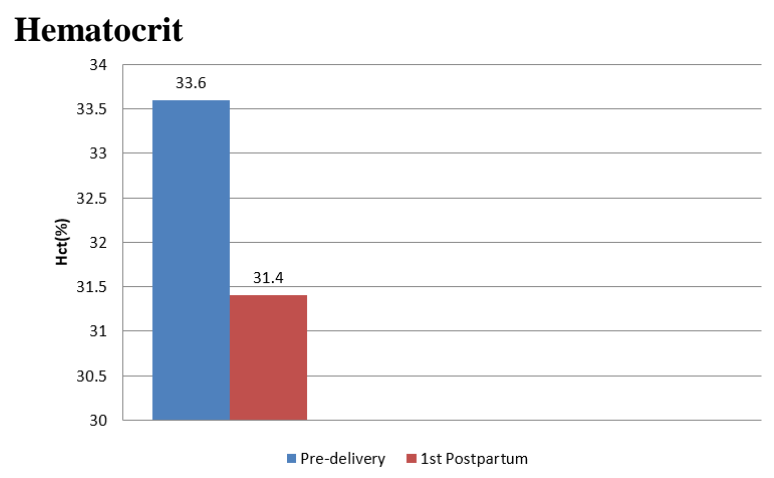

Fig. 2: Mean values of Hematocrit during predelivery and $1^{\text {st }}$ postpartum day

RBC:

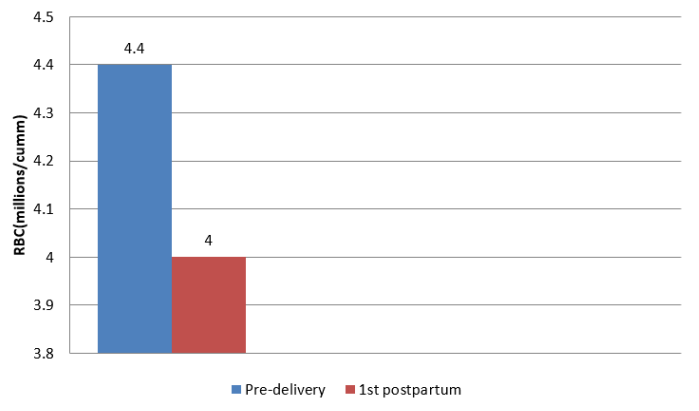

Fig. 3: Mean values of RBC count during predelivery and $1^{\text {st }}$ postpartum day

\section{Discussion}

This is a prospective cohort study conducted in the Obstetrics and Gynaecology department of Mc Gann Hospital, SIMS, Shivamogga. The study included 500 pregnant females who were undergoing vaginal delivery. Haematological parameters were analysed as explained in materials and methods.

In initial few days of puerperium, the haemoglobin concentration decreases because of dilution of blood due to transfer of tissue fluids into the circulation to replace the variable but inevitable loss of blood at delivery. Maternal haemoglobin level tends to fall during puerperium, and is significantly lower than the levels during the last two trimesters of pregnancy. ${ }^{7}$ The haemoglobin falls during the first 4 postpartum days, even in the absence of clinical postpartum haemorrhage, with a range up to $3.5 \mathrm{~g} / \mathrm{dl} .^{8}$

Studies have reported that the haematocrit, already low during normal pregnancy, decreases further during the first four days post delivery, thereafter progressively increasing to non-pregnant values. This puerperal decrease may reflect the change in plasma volume during this time; the already expanded plasma volume, which reaches a maximum during the third trimester of pregnancy, is further increased by up to $1200 \mathrm{ml}$ during the first four days following delivery. Another possibility would be that the rate of red cell destruction increases during the first day of puerperium leading to a decreased haematocrit. It has been reported that women given oral iron supplementation during pregnancy have larger red cells. It could be that selective destruction of these larger red cells allied to a transient increase in plasma volume during the early puerperium accounts for the initial fall in haematocrit. ${ }^{8}$

A study conducted by William's showed that, normally, during the first few post partum days, haemoglobin concentration and haematocrit fluctuate moderately. If they fall much below the levels present just prior to labour a considerable amount of blood has been lost. ${ }^{9}$

'One year cross sectional study of standardized visual estimation of blood loss during vaginal delivery and its correlation with hematocrit changes' by Laxmi $\mathrm{BV}$ reported fall in pre-delivery Hct value from $35.3 \pm$ 4.1 to $33.1 \pm 3.7$ on $1^{\text {st }}$ post-partum day, which is consistent with our study finding of pre-delivery Hct value of $33.6 \pm 3.3 \%$ and its fall during $1^{\text {st }}$ postpartum day to $31.4 \pm 3.3 \% .^{10}$

In present study, pre-delivery RBC count was $4.4 \pm$ 0.5 millions/cumm of blood which goes in line with the studies by Gebreweld A on 'Hematological profile of pregnant women at St. Paul's Hospital Millennium Medical College, Addis Ababa, Ethiopia' showing predelivery RBC count of $4.46 \pm 0.47 .{ }^{11}$ A study on 200 cases for 'haematological and haemodynamic changes around puerperium' by Kumar RA showed similar findings for pre-delivery RBC count $(3.8 \pm 0.5)$ which decreased to $3.3 \pm 0.49$ on $1^{\text {st }}$ post-partum day which is consistent with our study findings. ${ }^{12}$

Women with $\mathrm{Hb}$ levels below this $(\mathrm{HGB}<10)$ are more likely to develop primary $\mathrm{PPH}$, even with minor blood losses as this could lead to haemodynamic compromise. Studies have shown that anaemia is estimated to be responsible for $17-46 \%$ of cases of maternal death when combined with obstetric haemorrhage and that complications of $\mathrm{PPH}$, pre-term delivery and foetal growth restriction are more frequent in anaemic women. ${ }^{13,14}$

Ability to determine accurately the blood loss during childbirth is of extreme importance in the 
diagnosis and management of PPH. It has been suggested that estimation of the exact amount of blood loss is subjective and hence no gold standard method for estimation in most facilities. This can lead to a gross underestimation of PPH by up to $50 \%$.Studies proved that visual estimation is unreliable for the diagnosis of primary PPH.

Studies where visual estimation was compared with other methods, the prevalence of PPH was $8.9 \%$ and $16.2 \%$ by visual estimation and with changes in haematocrit respectively, an underestimation by the former. ${ }^{15}$ The use of a change in haematocrit of more than $10 \%$ as a method of diagnosis of PPH compared to VEBL at delivery is more sensitive in diagnosis of PPH as demonstrated by some studies. ${ }^{16-18}$ In the present study, the incidence of primary PPH was $14.8 \%$.

\section{Conclusion}

PPH is one of the leading cause of maternal deaths in the developing countries. The changes in haematological parameters, in particular the haematocrit changes during pre and post-delivery state helps to assess the incidence of primary PPH. By this, necessary measures can be taken to prevent it and thus can decrease the maternal morbidity and mortality.

Laboratory analysis of haematological parameters being simple and accurate method, has to be followed not only prior to delivery but also during postpartum period to assess primary $\mathrm{PPH}$.

\section{References}

1. Bamaiyi AJ, Adelaiye AB, Igbokwe VU. Relationship between anthropometric and haematological parameters among third trimester pregnant women in Sokoto State, Northwest Nigeria. Niger. J. Physiol. Sci. December 2013;28:211-9.

2. Rath WH. Postpartum hemorrhage-update on problems of definitions and diagnosis. Acta Obstet Gynecol Scand 2011;90:421-8.

3. Karpati PC, Rossignol M, Pirot M, Cholley B, Vicaut E, Henry $\mathrm{P}$, et al. High incidence of myocardial ischemia during postpartum hemorrhage. Anesthesiology 100;2004 :30-6; discussion 35A.

4. India. Office of the registrar general. Special bulletin on Maternal Mortality in India 2010-2012. New Delhi. Ministry of home affairs; 2013. Available from: http://www.censusindia.gov.in/vital_statistics/SRS_Bulletin s/MMR_Bulletin-2010-12.pdf

5. Berg CJ, Atrash HK, Koonin LM, Tucker M. Pregnancyrelated mortality in United States, 1996;88:161-7.

6. Coker A, Oliver R. Definitions and classifications Postpartum haemorrhage;(16):129-32.

7. Kurhade GA. Khanorkar SV. Puranik BM. Kher JR. Patwardhan SA. Agrawal S. Serum level of iron and transferrin in pregnancy and postpartum period. Indian $\mathrm{J}$ Physiol Pharmacol 1994;38:34-48.

8. Taylor DJ. Lind T. Puerperal haematological indices. Br J Obstet Gynaecol 1981;88:601-6.

9. Cunningham FG. Leveno KJ. Bloom SL. Hauth JC. Rouse DJ. Spong CY, editors. Williams obstetrics. $23^{\text {rd }}$ ed. United
States of America: The McGraw-Hill companies; 2010. P:649.

10. Laxmi BV. One year cross sectional study of standardised visual estimation of blood loss during vaginal delivery and its correlation with haematocrit changes; 2006.

11. Gebreweld A. Hematological profile of pregnant women at St. Paul's Hospital Millennium Medical College, Addis Ababa, Ethiopia; June 2015.

12. Kumar RA. Haematological and haemodynamic changes around puerperium, a study of 200 cases; March 2006.

13. Carroli G, Cuesta C, Abalos E. and Gulmezoglu AM. Epidemiology of postpartum haemorrhage: a systematic review. Best Pract Res Clin Obstet Gynaecol 2008;22:9991012.

14. Fareh OI. Rizk DE. Thomas L. Berg B. Obstetric impact of anaemia in pregnant women in United Arab Emirates. $J$ Obstet Gynaecol 2005;(25):440-4.

15. Wangwe PJT, Balandya B. Accuracy in diagnosis of postpartum haemorrhage using visual estimated blood loss versus change in haematocrit in a tertiary teaching hospital in Tanzania. Tanzania Journal of Health Research. 2012; vol 14,no 2:1-9.

16. Hofmeyr GJ, Walraven G, Gulmezoglu AM, Maholwana B, Alfirevic Z. \& Villar J. Misoprostol to treat postpartum haemorrhage: a systematic review. BJOG, 2005;112:54753.

17. Okonofua F. Misoprostol and women's health in Africa. African Journal of Reproductive Health 2005;9:7-9.

18. Parsons SM, Walley RL, Crane JM. \& Matthews K, Hutchens D. Oral misoprostol versus oxytocin in the management of the third stage of labour. Journal of Obstetrics and Gynaecology Canada, 2006;28:20-6. 